\title{
A role of an Enterprise Identification Card in a building process of water tourist investments
}

\author{
Emilia Miszewska ${ }^{1, *}$, Adam Bolt ${ }^{2}$, and Magdalena Apollo ${ }^{1}$ \\ ${ }^{1}$ Gdańsk University of Technology, Faculty of Civil and Environmental Engineering, Department of Construction Management and \\ Earthquake Engineering, Narutowicza 11/12 Str., 80-233 Gdańsk, Poland \\ ${ }^{2}$ Gdańsk University of Technology, Faculty of Civil and Environmental Engineering, Department of Geotechnics, Geology and Marine \\ Civil Engineering, Narutowicza 11/12 Str., 80-233 Gdańsk, Poland
}

\begin{abstract}
An essential element of a building process for water tourist investments in Poland is a document called the Enterprise Identification Card. It is required for the investments, which are classified according to the Regulation [1] as the ones that could potentially impact the environment. It is assumed that KIP is there to protect the environment against the excessive human interference and it just provides the guidelines regarding the enterprise completion for an applicant. TOWS-SWOT analysis has been used in order to conduct an accurate evaluation of a role of the Enterprise Identification Card in a building process of water tourist investments. It is one of the modifications of the basic method of strategic analysis SWOT.
\end{abstract}

\section{Introduction}

An essential element of a building process for most water tourist investments in Poland is a necessity to obtain a decision about the environmental conditions (an environmental decision for short). In order to be granted the environmental decision, the Enterprise Identification Card (KIP for short) should be prepared in the correct way.

A decision about the environmental conditions is a document, which defines the environmental conditions for the completion of an enterprise in the most environment friendly way. In the documents an enterprise is described as a building plan or another environmental impact, which transforms or changes the way of an area is used, including ore extraction.

An enterprise information card is a document, which should include basic information about a planned building enterprise. It should characterize an enterprise in such a way that the information included allows to identify an investment, its scope and some basic parameters. KIP is required when a planned enterprise is numbered among the enterprises, which could potentially have a significant impact on the environment. It is a group of enterprises defined in $\$ 3$ of The Council of Ministers Regulation on the enterprises, which could have a significant environmental impact (Journal of Laws 2010, No.213, item 1397 as amended) [1] and in Appendix II of the Council Directive No 85/337/EWG about an assessment of the impact of some enterprises on public and private environment [2].

KIP should also be obtained in the case when an investor applies for a decision about the environmental conditions for an enterprise which could have a significant impact on the environment. These are included in $\S 2$ of the above-mentioned regulation [1] and in the Appendix of I Council Directive No 85/337/EWG [2], however, it is only the case when an applicant does not include a report and requests removal of a scope of the report from the application [3].

The aim of the publication is to indicate a positive and a negative role of an Enterprise Identification Card and its strengths and weaknesses in a building process by means of TOWS-SWOT analysis for water tourist investments.

\section{A role of an Enterprise Identification Card in an investment process}

Figures and tables, as originals of good quality and well contrasted, are to be in their final form, ready for reproduction, pasted in the appropriate place in the text. Try to ensure that the size of the text in your figures is approximately the same size as the main text (10 point). Try to ensure that lines are no thinner than 0.25 point. An Enterprise Identification Card should be prepared for the investments, which could potentially have a significant impact on the environment. Water tourist investments such as a construction or reconstruction of canoe harbours and marinas, a construction and reconstruction of platforms and water tram stops are usually classified as this group.

In most procedures, an investor obliges a designer to obtain an environmental decision and to prepare KIP. As the research shows, waiting time for granting an environmental decision is [4] the main reason for the extension of an investment process. The problem is multifaceted and results from the incorrect preparation of KIPs, the wrong enterprise classification as the ones

\footnotetext{
* Corresponding author: emiurban@pg.edu.pl
} 
which could have significant impact on the environment, too many cases for each official, lack of technical knowledge among the officials employed to issue a decision, or various law interpretations among the institutions involved in a process of issuing of an environmental decision. As a result, not only an construction process is extended, but there could also be a necessity to prepare a report about an impact of an enterprise on the environment and a refusal to issue an environmental decision, which is essential in order to obtain a construction permit or to report construction work for building investments in Poland. Problems with obtaining an environmental decision result in imposing large financial penalties on a designer by an Investor or/and impairment of a subsidy from external sources by an Investor and suspension or abandonment of an enterprise. The process of obtaining an environmental decision and a role of an Enterprise Identification Card is presented on Figure 1.

An application for a decision on environmental conditions along with an Enterprise Identification Card and the required attachments

A Commune Head/Mayor/President of a City

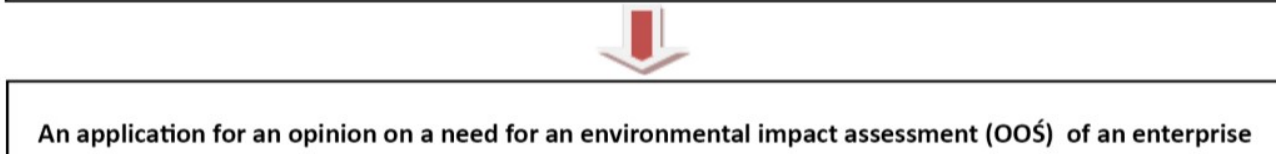

An application for an opinion on a need for an environmental impact assessment (OOŚ) of an enterprise

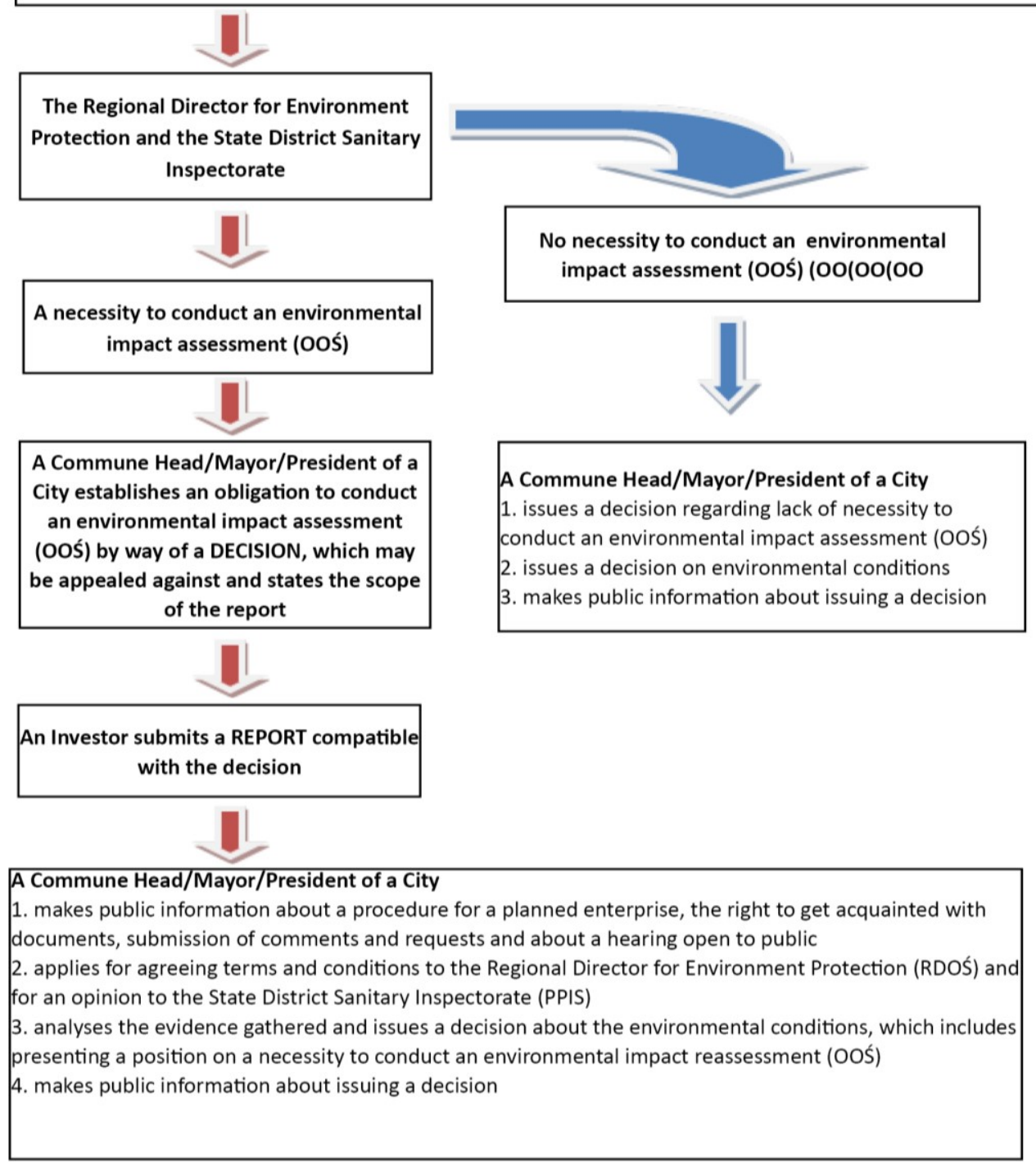

Fig. 1. The proceedings for issuing of the environmental decision for enterprises which could have significant environmental impact (own study based on [3]). 


\section{The research methodology}

The SWOT method together with its variations is a universal tool and widely used, because it allows analyzing various research objects, i.e .:

- urban development planning - a strategy for the city of Dar es Salaam in Tanzania in his publication $A$ SWOT analysis of strategical urban development planning: The case of Dar es Salaam city in Tanzania F. Halla [5];

- university development - an example is the University of Warwick, whose strategy was presented by Robert G. Dyson in the work Strategic development and SWOT analysis at the University of Warwick [6];

- teams and organizations - this is one of the most popular research area for scholars using SWOT analysis. In the paper by S. E. Jackson, A. Joshi and N. L. Erhardt, Recent Research on Team and Organizational Diversity: SWOT Analysis and Implications [7], it was used to assess the effects of diversity of jobs in teams and organizations;

- evaluation of various sectors of the economy - an example is the publication of Regional Energy planning through SWOT analysis and strategic planning tools .: Impact on renewables development, by J. Terrados, G. Almonacid, L. Hontoria [8] and SWOT Analyzes of the National Energy sector for sustainable Energy development presenting the results of research by the scientists Markovska N., Taseski V., Pop-Jordanova [9]; - development of companies, enterprises and products presented in the following publications: A knowledgebased SWOT - analysis system as an intrument for strategic planning in small and medium sized enterpises [10] and SWOT analysis: It's time for a product recall [11].

SWOT analysis can be equally useful in use with other methods present in the article Utilizing the analytic hierarchy process (AHP) in SWOT analysis - a hybrid method and its application to a forest-certification case [12] or Application of a quantification SWOT analytical method [13].

SWOT analysis is based on a basic classification diagram of factors, which influence current and future condition of a researched structure. The factors can be classified into external and internal and those impacting in a positive or negative way. Mixing these two types of classifications generates four categories of factors:

- External positive- opportunities,

External positive factors, otherwise known as opportunities, are possibilities to use a situation in the surrounding of a researched structure in order to achieve the aim pursued. If they are identified early and correctly, they will constitute a development impetus, or they will allow to limit the risks.

- External negative- threats

Factors within the environment of a researched structure, namely threats, are barriers constituting danger of an adverse change taking place [14], which causes delays, incomplete aim achievement or its complete failure. It often leads to additional costs, efforts and outlays [14].
- Internal positive- strengths,

Strengths are the advantages of a researched structure causing an object in question to stand out, which allows to obtain an advantage.

- Internal positive- strengths,

Internal conditions (the features of a researched structure, which are dependent on it) constitute a weakness, a defect or some negative conditions effecting the building of an advantage (strength) or even constituting a barrier to this process [14].

The above mentioned classification can be presented in a schematic way (see Figure 2).

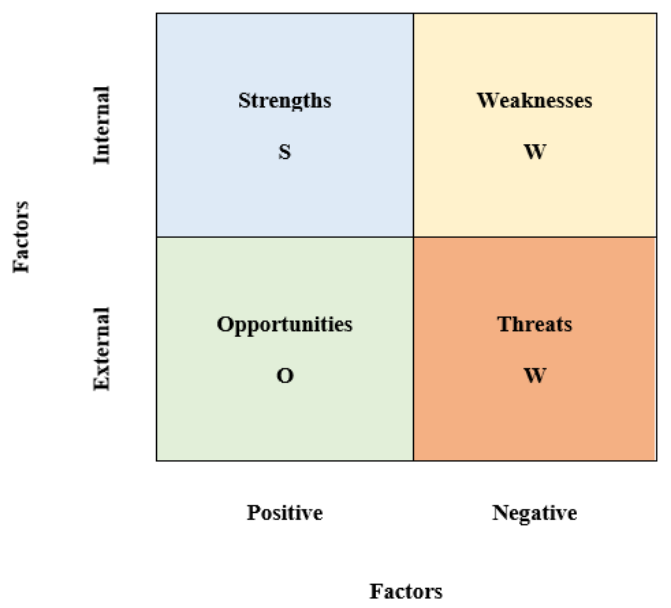

Fig. 2. The classification of factors in SWOT analysis [own study].

In the literature, many modifications of the basic concept of SWOT analysis can be specified. It is due to various approaches among the authors regarding the essence, the aim and the perspective of conducting the research. The most common modifications include WOT's- up analysis, TOWS analysis and TOWS-SWOT analysis [15].

The latter is a combination of TOWS analysis and SWOT analysis and it aims at conducting the analysis from the inside to the outside and from the outside to the inside. This approach allows not only to conduct a complex assessment of the weak and the strong points of the researched object and its opportunities and threats in the environment, but also to identify how the researched object impacts the environment and how the environment impacts the object.

General objectives of conducting TOWS-SWOT analysis consist of 10 steps presented below [own study based on [15]:

1. Indicating the aim of the analysis and characterising the diagnosed object.

2. Identifying as many as possible factors which impact the object and their characterising them.

3. Grouping the factors into sets $\mathrm{S} / \mathrm{W} / \mathrm{O} / \mathrm{T}$.

4. Classifying the factors as one of the three subgroups (factors type A- relevant, factors type B- less relevant, factors type $\mathrm{C}$ - the least relevant).

Corresponding author: emiurban@pg.edu.p1 
5. Development of the potential strategic variants:

- aggressive strategy (SO) maxi-maxi,

- conservative strategy (ST) maxi- mini,

- competitive strategy (WO) mini-maxi,

- defensive strategy (WT) mini- mini.

6. Assigning weights to particular factors in the set in such a way that their sum is 1 .

7. Using 8 cross tables to indicate correlation between the factors assigning them value 0,1 or 2 .

8. Performing calculations for each of the 8 cross tables and placing the results in the summary

9. Interpretation of the results based on the information from the summary table.

10. Choosing a suitable action strategy for a design/organization for the period of conducting the analysis.

\section{TOWS-SWOT analysis as a tool for assessing a role of an EIC in a building process of water tourist investments}

TOWS-SWOT analysis has been used in order to assess a role of an Enterprise Identification Card in a building process of water tourist investments. The strong and weak points, defined as the matters of elaboration and content of the document, that is the internal surroundings, have been identified. The external surroundings is considered as opportunities and threats, that is the procedures connected with KIP, legal acts, etc.

The factors classified to particular groups and their weights have been presented in Table 1. Having performed calculations for each of the 8 cross tables, the summary table has been developed - Table 2 . The choice of a suitable strategy has been made, based on the results of the TOWS-SWOT analysis summarized in Table 3.

Table 1. An assessment of the strength of the influence of particular conditions.

\begin{tabular}{|c|c|c|c|c|c|}
\hline \multirow{2}{*}{ Code } & \multicolumn{2}{|r|}{ Internal factors } & \multirow{2}{*}{ Code } & \multicolumn{2}{|r|}{ External factors } \\
\hline & Weight & The strong points & & Weight & Opportunities \\
\hline $\mathrm{S} 1$ & 0.3 & $\begin{array}{l}\text { KIP aims to specify the conditions } \\
\text { necessary for an investment to be } \\
\text { completed }\end{array}$ & $\mathrm{O} 1$ & 0.2 & $\begin{array}{l}\text { Employing more people to process KIP and issue } \\
\text { decisions }\end{array}$ \\
\hline $\mathrm{S} 2$ & 0.2 & $\begin{array}{l}\text { A necessity to describe the applied } \\
\text { technology by an Investor allows to verify } \\
\text { the possibility of the nature protection }\end{array}$ & $\mathrm{O} 2$ & 0.3 & $\begin{array}{l}\text { Establishing the maximum time of } 2 \text { months for the } \\
\text { consideration of KIP and issuing a decision }\end{array}$ \\
\hline S3 & 0.2 & $\begin{array}{l}\text { A necessity to state a type and anticipated } \\
\text { quantity of substances or energy released } \\
\text { to the environment when applying } \\
\text { methods, which protect the environment }\end{array}$ & $\mathrm{O} 3$ & 0.2 & Simplification of KIP preparation in the future \\
\hline S4 & 0.1 & The detailed nature of KIP & $\mathrm{O} 4$ & 0.1 & Reduction of the submitted attachments \\
\hline \multirow[b]{2}{*}{ S5 } & \multirow[b]{2}{*}{0.2} & \multirow{2}{*}{$\begin{array}{l}\text { A necessity to state the anticipated } \\
\text { amount of water, resources, materials, } \\
\text { fuels and energy used in the period of } \\
\text { enterprise and exploitation }\end{array}$} & O5 & 0.1 & $\begin{array}{l}\text { Establishing one institution processing KIP in each } \\
\text { voivodship }\end{array}$ \\
\hline & & & O6 & 0.1 & $\begin{array}{l}\text { Taking over a necessity to indicate application of } \\
\text { specific eco-friendly solutions by competent officials } \\
\text { with technical knowledge }\end{array}$ \\
\hline Total & 1.0 & & Total & 1.0 & \\
\hline \multirow{2}{*}{ Code } & \multicolumn{2}{|r|}{ Internal factors } & \multirow{2}{*}{ Code } & \multicolumn{2}{|r|}{ External factors } \\
\hline & Weight & The weak points & & Weight & Threats \\
\hline W1 & 0.2 & $\begin{array}{l}\text { Although at this stage the arrangements } \\
\text { regarding a specific variant of an } \\
\text { investment are on the way, in KIP all the } \\
\text { variants of the enterprise must be defined }\end{array}$ & $\mathrm{T} 1$ & 0.1 & $\begin{array}{l}\text { A necessity for an investor to classify the enterprises } \\
\text { which can potentially have a significant impact on } \\
\text { the environment }\end{array}$ \\
\hline W2 & 0.15 & $\begin{array}{l}\text { The numerous necessary attachments to } \\
\text { KIP }\end{array}$ & $\mathrm{T} 2$ & 0.1 & Common requests to supplement KIP \\
\hline W3 & 0.25 & $\begin{array}{l}\text { A necessity for the applicant to refer to all } \\
\text { possible forms of the environment } \\
\text { protection }\end{array}$ & $\mathrm{T} 3$ & 0.1 & $\begin{array}{l}\text { Too high employment costs of a specialist } \\
\text { environmental company for an applicant }\end{array}$ \\
\hline W4 & 0.15 & $\begin{array}{l}\text { A difficulty with the correct preparation } \\
\text { of KIP }\end{array}$ & $\mathrm{T} 4$ & 0.2 & A complicated procedure \\
\hline \multirow[t]{2}{*}{ W5 } & \multirow[t]{2}{*}{0.25} & \multirow[t]{2}{*}{$\begin{array}{l}\text { A necessity to describe potential cross- } \\
\text { border impacts on the environment by an } \\
\text { applicant }\end{array}$} & $\mathrm{T} 5$ & 0.4 & $\begin{array}{l}\text { Delays or a lack of investment implementation, } \\
\text { especially from the state budget grants or foreign } \\
\text { funds }\end{array}$ \\
\hline & & & T6 & 0.1 & $\begin{array}{l}\text { Lack of technical knowledge among the officials } \\
\text { issuing an environmental decision }\end{array}$ \\
\hline Total & 1.0 & & Total & 1.0 & \\
\hline
\end{tabular}


Table 2. The summary of the results of the performed SWOT-TOWS analysis assessment of the strength of the influence of particular conditions.

\begin{tabular}{|c|c|c|c|c|c|c|}
\hline Combination & \multicolumn{2}{|c|}{ Results of SWOT analysis } & \multicolumn{2}{c|}{ Results of TOWS analysis } & \multicolumn{3}{c|}{$\begin{array}{c}\text { Summary results of } \\
\text { SWOT/TOWS }\end{array}$} \\
\hline & $\begin{array}{c}\text { The sum of the } \\
\text { interactions }\end{array}$ & $\begin{array}{c}\text { The sum of the } \\
\text { products }\end{array}$ & $\begin{array}{c}\text { The sum of the } \\
\text { interactions }\end{array}$ & $\begin{array}{c}\text { The sum of the } \\
\text { products }\end{array}$ & $\begin{array}{c}\text { The sum of the } \\
\text { interaction }\end{array}$ & $\begin{array}{c}\text { The sum of } \\
\text { the products }\end{array}$ \\
\hline S/O & 32 & 5.5 & 48 & 8.8 & 80 & 14.3 \\
\hline S/T & 56 & 11.6 & 58 & 11.9 & 114 & 23.5 \\
\hline W/O & 44 & 9.4 & 56 & 11.45 & 100 & 20.85 \\
\hline W/T & 54 & 9.45 & 64 & 11.9 & 118 & 21.35 \\
\hline
\end{tabular}

Table 3. A selection of a strategy based on the results received upon the analysis.

\begin{tabular}{|c|c|c|c|}
\hline \multirow{2}{*}{$\begin{array}{c}\text { The strong } \\
\text { points } \\
{[\mathbf{S}]}\end{array}$} & Opportunities & \multicolumn{1}{|c}{ Threats } & \multirow{1}{*}{ T } \\
\cline { 2 - 3 } & Aggresive strategy & $\begin{array}{c}\text { Conservative } \\
\text { strategy }\end{array}$ & \\
\cline { 2 - 3 } & 80 & 114 & The sum of number of interactions \\
\cline { 2 - 3 } & 14.3 & 23.5 & The sum of the weighted number of interactions \\
\hline \multirow{2}{*}{$\begin{array}{c}\text { The weak } \\
\text { points } \\
{[\mathbf{W}]}\end{array}$} & Competitive strategy & Defensive strategy & \\
\cline { 2 - 3 } & 100 & $\mathbf{1 1 8}$ & The sum of number of interactions \\
\cline { 2 - 3 } & 20.85 & $\mathbf{2 1 . 3 5}$ & The sum of the weighted number of interactions \\
\hline
\end{tabular}

In consequence of the performed calculations, the result obtained indicates that a role of an Enterprise Identification Card in a building process of water tourist investments is defensive. It is a situation where there are more threats than opportunities and the weak aspects dominate over the strong ones in the external surroundings. That means that KIP is a complicated and time - consuming document to prepare. It requires attaching many documents, which in most cases an applicant must acquire at a charge, despite the fact that the institution dealing with KIP has free access to this information. The identification of the alternative variants for an enterprise is rather illusory because most of the arrangements required by law and the construction design itself is virtually ready at this stage. Individuals presenting the alternative solutions do not concentrate on proposing better or equal design variants, but they present the worse ones so the variant chosen by the Investor is the better one for the institution considering the submitted KIP. The necessity to refer to all possible forms of the environmental protection and potential transboundary impacts on the environment is difficult to formulate for a person preparing a project due to number of data and lack of specialist knowledge. In most cases, an applicant cannot afford to employ specialists to formulate KIP. Unfortunately, companies specializing in development of documents and environmental analysis are often on the side of the authority issuing an environmental decision. Moreover, these services are not cheap and their cost is often not included in execution of tenders [16]. As a consequence, an applicant prepares

KIP on his or her own. A problem appears when there is a necessity to classify an enterprise as the one which can potentially impact the environment or can impact the environment in a significant way. However, the lack of knowledge on the part of an applicant is not the only reason for problems with drawing up of KIP. The lack of professional technical knowledge on the scope of construction among the officials causes misunderstandings and complications in the procedure of issuing an environmental decision. The frequent calls upon supplements or explanations and lack of possibility to achieve a consensus between an applicant and an official very often results in a few months long delays in an investment process, or in the worst cases, in suspension of the completion of an investment and loss of grants from the state budget or foreign funds.

\section{Conclusions}

An Enterprise Identification Card (KIP) is a document required by the law system of the environmental protection in Poland for the enterprises which could have a significant impact on the environment. Most water tourist investments are included in this category. KIP is supposed to specify the conditions under which a building construction can be completed. However, as the TOWS-SWOT analysis has shown, a role of an Enterprise Identification Card has a defensive character. It means that instead of facilitating the investment process, it complicates it to a significant extent. The reason is the fact that everybody can prepare KIP, hence the main infringements are on the part of the applicants already at a preliminary stage, related to the formal requirements and the classification of an enterprise. Each infringement in documents not only contributes to the increase of waiting time for a decision, but it also raises the costs of an enterprise or its suspension [4]. 
According to the authors, the result of the analysis should be the reason for a debate on simplification of not only the procedure of granting the environmental decision itself, but also on delegating the necessity of formulating the guidelines for the environmental protection in a given area in an investment process to the officials, who possess greater knowledge in this regard than an applicant. That of course means an increasing the number of employees who would verify the content of KIP, but it could also considerably reduce the waiting time for an environmental decision. In consequence, the progress of a building process, including inter alia water tourist investments would be significantly improved.

\section{References}

1. The Council of Ministers Regulation of 9 November 2010 on the enterprises, which could have a significant environmental impact. Journal of Laws 2010, No.213, item 1397 as amended.

2. The Council Directive of 27 June 1985, No $85 / 337 /$ EWG about an assessment of the impact of some enterprises on public and private environment

3. P. Wójcik, Decyzja o środowiskowych uwarunkowaniach oraz ocean oddziaływania przedsięwzięcia na środowisko, Poradnik dla Inwestora, access: 15 December 2017, http://www.korfantow.pl/download/attachment/2863 0/decyzja-o-srodowiskowych-uwarunkowaniachoraz-ocena-oddzialywania-przedsiewziecia-nasrodowisko-poradnik-dla-inwestora.doc, (2015) (in polish)

4. L. Korona, Uwarunkowania realizacji planowanych przedsięwzięć budowlanych z uwzględnieniem wymogów ochrony środowiska, Zeszyty Naukowe Politechniki Gdańskiej, Budownictwo Lądowe, 61, 15-22 (2007)

5. F. Halla, A SWOT analysis of strategic urban development planning: The case of Dar es Salaam city in Tanzania, Habitat International, 31, 130-142, (2007)

6. R. G. Dyson, Strategic development and SWOT analysis at the University of Warwick, European Journal of Operational Research, 152(3), 631-640, (2004)
7. S. E. Jackson, A. Joshi, N.L. Erhardt, Recent Research on Team and Organizational Diversity: SWOT Analysis and Implications, Journal of Management, 29(6), 201-830, (2003)

8. J. Terrados, G. Almonacid, L. Hontoria, Regional energy planning through SWOT analysis and strategic planning tools.: Impact on renewables development, Renewable Susainable Energy Reviews, Elsevier, 11(6), 1275-1287, (2007)

9. N. Markovska, V.Taseska-Gjorgievska, J. popJordanov, SWOT analyses of the national energy sector for sustainable energy development, Energy, 34(6), 752-756, (2009)

10. G. Houben, K. Lenie, K. Vanhoof, A knowledgebased SWOT-analysis system as an instrument for strategic planning in small and medium sized enterprises, Decision Support Systems, 26(2), 125135, (1999)

11. T. Hill, R. Westbrook, SWOT analysis: It's time for a product recall, Long Range Planning, 30(1), 4652, (1997)

12. M. Kurttila, M. Pesonen, J. Kangas, M. Kajanus, Utilizing the analytic hierarchy process (AHP) in SWOT analysis - a hybrid method and its application to a forest-certification case, Forest Policy and Economics, 1, 41-52, (2000)

13. H.H. Chang, W.Ch. Huang, Application of a quantification SWOT analytical Method, Mathematical and Computer Modeling, 43, 158169, (2006)

14. W. R. Griffin, Podstawy zarzadzania organizacjami, Wydawnictwo Naukowe PWN, Warsaw, 250-253 (2004) (in polish)

15. M. Nowicki, SWOT, scientific editing: K. Szymańska, Kompendium metod $i$ technik zarzadzania. Teoria $i$ ćwiczenia, Printing house a Wolters Kluwer business, Warsaw, 325-354 (2015) (in polish)

16. B. Grzyl, E. Miszewska-Urbańska, M. Apollo, The life cycle cost of a building from the point of view of environmental criteria of selecting the most beneficial offer in the area of competitive tendering, E3S Web of Conferences, 17, 00028 (2017) 